\title{
Total Content of Polyphenols and Antioxidant Activity of Different Melliferous Plants
}

\author{
Claudia PAȘCA, Liviu Al. MĂRGHITAȘ, Otilia BOBIŞ*, Daniel S. DEZMIREAN, Rodica MĂRGĂOAN, Carmen \\ MUREŞAN \\ Department of Beekeeping and Sericulture, Faculty of Animal Science and Biotechnologies, University \\ of Agricultural Sciences and Veterinary Medicine - 400372, Cluj-Napoca, Mănăștur, 3-5, România \\ *corresponding author, e-mail: obobis@usamvcluj.ro
}

Bulletin UASVM Animal Science and Biotechnologies 73(1)/ 2016

Print ISSN 1843-5262; Electronic ISSN 1843-536X

DOI:10.15835/buasvmcn-asb: 11762

\begin{abstract}
In this study polyphenols content and antioxidant activity of melliferous plants for the following: mint (Mentha pulegium), burdock (Arctium lappa), comfrey (Symphytum officinale), plantain (Pantago lanceolata), thyme (Thymus vulgaris), sage (Salvia officinalis), marigold (Calendula officinalis), small marshmallow (Althaea officinalis), echinacea (Echinaceea angustifolia) and black popular (Populus nigra) were investigated, using two different extraction methods.

High content of polyphenols and flavones were extracted from Populus nigra, with an average of both extractions of $23.14 \mathrm{mg} \mathrm{GAE} / \mathrm{g}$ and $78.07 \mathrm{mg} \mathrm{QE} / \mathrm{g}$ flavones. Among the studied plants, Arctium lappa registered the highest antioxidant activity $(0.129 \mathrm{mmol}$ Trolox $/ \mathrm{mL})$ in alcoholic extract and Echinaceea angustifolia with a value of $0.122 \mathrm{mmol}$ Trolox/mL in aqueous extract. The lowest values were recorded for the antioxidant activity of Althaea officinalis (alcoholic extract) and Arctium lappa (aqueous extract). The results show that Arctium lappa, Echinaceea angustifolia and Populus nigra can be considered melliferous plants for their high biologically active compounds potential and bee products (honey and pollen) having the composition of these plants could have high antioxidant and antibacterial properties.
\end{abstract}

Keywords: melliferous plants, extraction methods, DPPH, polyphenols, flavones.

\section{INTRODUCTION}

Bee products are popular, traditional healthy foods. The source of their properties are melliferous plants, their secondary metabolites present in the nectar and pollen, which have been recognized as an important source of antioxidants (Skotti et al., 2013).

The melliferous plants are represented by the plants that bees visit for gathering nectar and pollen. There are pollen giving plants, nectar giving plants and mixed melliferous plants, giving both nectar and pollen. Bee product composition is tightly related to the botanical source of nectar and pollen, and also to the geographical area, because soil and weather determine diversification of melliferous flora (Pérez-Pérez et al., 2013; Antonie, 2014).
According to literature, the antioxidant capacity of bee products is due mainly to the phenolic compounds and flavonoids they contain, and there is a close relationship between polyphenols and antioxidant capacity (Alzahrani et al., 2012).

Some melliferous species are extremely valuable, due to the succession of blooming throughout the active season, and can ensure, together with melliferous trees and shrubs, harvesting for survival and production of the bee families.

In the literature there are more than 1,000 known species of melliferous plants, of which 200 are important for apiculture (Pârvu, 2005).

Melliferous plants often contain a wide variety of antioxidant molecules, such as phenolic 
compounds (e.g., phenolic acids, flavonoids), quinones and tannins, tocopherols, carotenoids and ascorbic acid. These natural antioxidants are distributed in different parts of the plant such as wood, bark, stems, pods, leaves, fruits, roots, flowers, pollen and seeds (Al-Mustafa et al., 2008). Antioxidants are stable molecules with extra electrons or with the ability to receive additional electrons. Antioxidants are considered the body's natural defense system against the harmful effects of free radicals. They protect cell structures and DNA from free radical effects of pests, contaminants or different diseases. Natural antioxidants draw scientists' attention because of their health benefits by preventing various chronic diseases caused by exposure to free radicals (Pryor, 1991). Edible and inedible plants show biological effects due to polyphenolic compounds that are directly proportional to antioxidant activity

(Wojdylo et al., 2007).

Melliferous plant species belonging to several botanical families, such as Compositae, Boraginaceae, Lamiaceae, Plantaginaceae, Asteraceae, Malvaceae, Salicaceae were studied.

Antioxidant properties have been studied for at least 50 years, using traditional methods; DPPH is the commonly used test for radical scavenging activities (Wojdylo et al., 2007).

Arctium lappa L. (Compositae) is a large perennial herbaceous plant that has been known sinceancienttimesforitsproperties, and nowadays it is used as a tincture, decoction, extract, and oil for gout, to treat rheumatism, and several skin diseases and as a diuretic and pathogenic agent (Azizov et al., 2012).

Symphytum officinalis (Boraginaceae) was used in folk medicine in externally applied poultices, to reduce joint inflammation, in the treatment of broken bones and tendon damages, in rheumatic and arthritic diseases (Neag et al., 2011).

Thymus vulgaris, Salvia officinalis and Mentha pulegium of the Laminaceae family were used for their pharmacological properties: antiinflamatory, antiviral, antifungical, antimicrobial and antioxidant (Naz et Anis, 2012; Herman, 2014 ).

Certain studies confirm that Plantago lanceolata (Plantaginaceae) has antiinflamatory, immunoregulatory, antioxidant and antispasmodic effects (Beara et al., 2012).
The contents of biologically active compounds were measured in extracts of Calendula officinalis; this plant is rich in flavonoids, especially aglycones and glycosides of flavonols, saponosides, lipids, organic acids and saccharids (Khalid and Teixeira de Silva, 2012).

Ghavi (2015) reported that the roots of Althaea officinalis form aqueous extract and polysaccharides were effective stimulators of epithelial cells in vitro due to their free radical scavenging activity.

The Populus species possess great potential for therapeutical applications, especially for their well-known anti-inflammatory properties, the antioxidant properties of propolis, a hive product, collected by honey bees mainly from poplar bud exudates (Dudonné et al., 2011).

In this study, polyphenols content and antioxidant activity of different meliferous plants were investigated, using two different solvents for extraction (water and ethanol).

\section{MATERIALS AND METHODS}

\subsection{Plant materials:}

Echinacea, marigold, thyme, mint, sage and black poplar were obtained from experimental fields of UASVM Cluj. Plants were harvested in the period of their maximum of bioactive principles, dried in the shade,in a well-aired place.

Burdock, comfrey, plantain and small marshmallow were purchased from Plafar Cluj. After drying, plant materials were grounded in fine powder and stored in paper bags until extract preparation.

\subsection{Preparation of alcoholic and aqueous extracts from plants}

To obtain alcoholic and aqueous extracts, $5 \mathrm{~g}$ of grounded plant were weighed and $100 \mathrm{ml} 96^{\circ}$ ethanol for alcoholic extract, and $100 \mathrm{ml}$ distilled water for aqueous extract were added. The flasks were kept for 14 days, protected from light at room temperature, stirring the content daily, after which the extracts were filtered through filter paper and the content was brought to $100 \mathrm{ml}$ with ethanol or water (Pașca et al., 2015).

\subsection{Determination of total phenol content}

Total Phenolic Content (TPC) in extracts was determined according to the Folin-Ciocâlteu procedure described by Shahmohamadi et al., (2014). In short, an aliquot of $25 \mu \mathrm{L}$ extracts (alcoholic or aqueous) was mixed with $125 \mu \mathrm{L}$ 
Folin Ciocâlteu $0.2 \mathrm{~N}$ and incubated at room temperature for $5 \mathrm{~min}$. Next, $100 \mu \mathrm{L}$ of sodium carbonate solution $(75 \mathrm{~g} / \mathrm{L})$ was added and allowed to stand for $2 \mathrm{~h}$ at room temperature. The absorbance of the reaction mixture was read at $760 \mathrm{~nm}$ using multichannel spectrophotometer (model Sinergy 2 Biotek).

A methanolic gallic acid solution (0.001$0.15 \mathrm{mg} / \mathrm{mL}$ ) was used for calibration curve construction.

The total phenol content was expressed as miligrams Gallic Acid Equivalents (GAE) per g of plant dry weight. All determinations were performed in triplicate (Ibrahim et al., 2013).

\subsection{Total flavones content}

The $\mathrm{AlCl}_{3}$ method was used for estimation of the flavone/flavonol content of the extracted samples. $150 \mu \mathrm{L}$ of $2 \% \mathrm{AlCl}_{3} \cdot 6 \mathrm{H}_{2} \mathrm{O}$ solution $(2 \mathrm{~g}$ in $100 \mathrm{ml}$ methanol) and equal volumes (150 $\mu \mathrm{L}$ ) of each extract were added. The mixture was vigorously shaken, and after 10 min of incubation, absorbance was read at $415 \mathrm{~nm}$. Flavonoid content was calculated from the calibration curve of quercetin standard solutions, and expressed as mg quercetin equivalent/g dry weight (Chang, 2007).

\subsection{Antioxidant activity}

The free radical scavenging activity was determined using 2,2-diphenyl-1-picrylhydrazyl (DPPH) radical described by Brand-Williams et al., (1995). This method is based on the reduction of stable DPPH when it accepts hydrogen from an antioxidant compound.
Radical scavenging activity of ethanol and aqueous extracts against stable DPPH was determined spectrophotometrically.

The change in colour (from deep-violet to light-yellow) was measured at $517 \mathrm{~nm}$ using multichannel spectrophotometer (model Sinergy 2 Biotek). Briefly, $40 \mu \mathrm{L}$ of each extracts was added to $200 \mu \mathrm{L}$ of fresh solution of DPPH in methanol, and mixed. The samples were kept in the dark for 20 min at room temperature, and then the decrease in absorption was measured. Each experiment was carried out in triplicate. Radical scavenging activity was calculated using the following relationship:

Inhibition $(\%)=\left(\left(A_{0}-A\right) / A_{0}\right) \times 100$, where $A_{0}$ - absorption of control, A - absorption of extract solution (Shahmohamadi et al., 2014).

As a positive control, we used Trolox (analogue of vitamin E) building a calibration curve with concentrations ranging from 0 to $0.025 \mathrm{mmol} / \mathrm{L}$. Trolox milliequivalents/mL of extract (by making a calibration curve with varying concentrations of Trolox $0.0125-0.1 \mathrm{mmol} / \mathrm{L}$ ). A milliequivalent antioxidant is defined as its ability to reduce a prooxidant milliequivalent.

\section{RESULTS AND DISCUSSION}

\subsection{Total Phenolic Content (TPC)}

Figure 1 shows the TPC of aqueous extract and 98\% EtOH extracts, using the Folin-Ciocâlteu method and the regression equation $\mathrm{y}=7.109 \mathrm{x}+$ $0.0499\left(R^{2}=0.999\right)$.

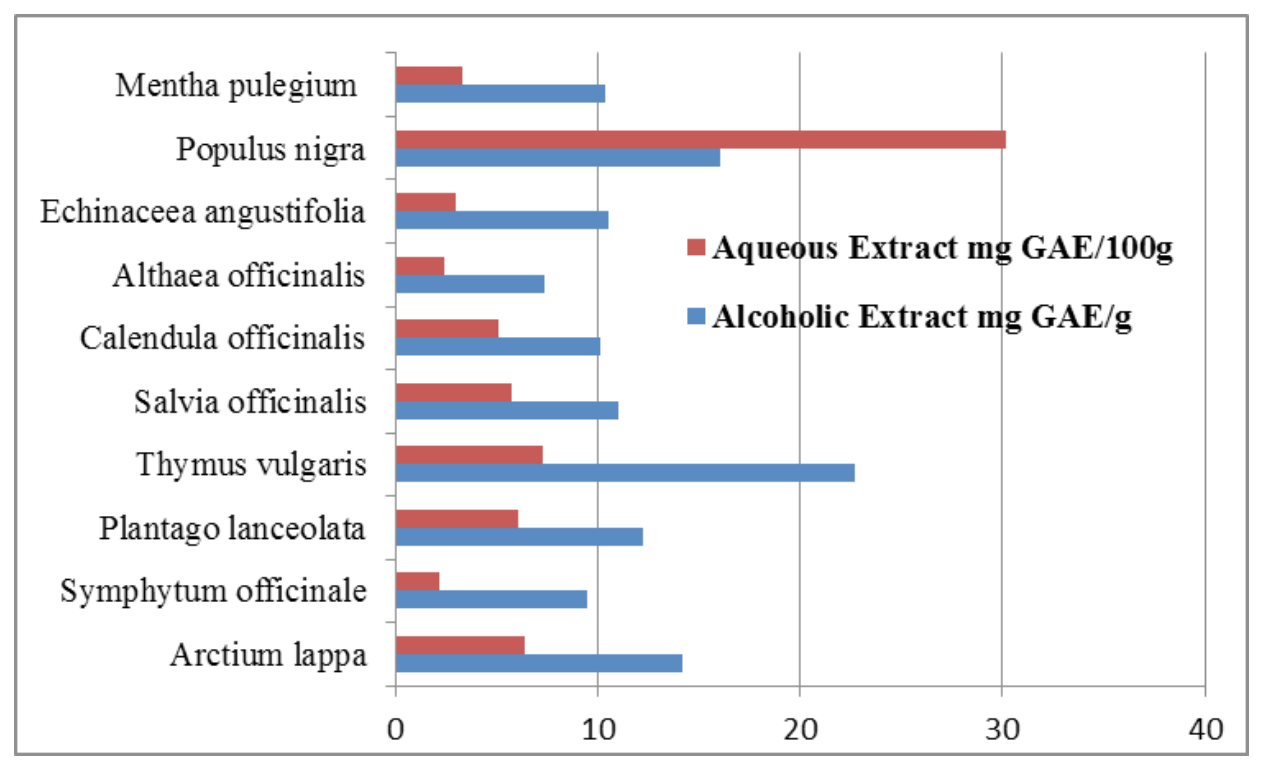

Note: GAE= gallic acid equivalents;

Fig.1. Total phenolic content (mg GAE/g) 
Extracts from 98\% EtOH showed that TPC was highest in the Thymus vulgaris extract $(22.67 \pm 0.003 \mathrm{mg} \mathrm{GAE} / \mathrm{g})$ and lowest in the Althaea officinalis extract (7.38 $\pm 0.032 \mathrm{mg} \mathrm{GAE} / \mathrm{g})$. For the aqueous extracts, the phenolic contents lie between $30.20 \pm 0.007 \mathrm{mg}$ GAE/g Populus nigra and $2.16 \pm 0.007 \mathrm{mg} \mathrm{GAE} / \mathrm{g}$ Symphytum officinale, respectively.

Phenolic compounds are secondary metabolites that have an important role in nutrition, in plant organoleptic properties, commercial properties, and stabilization of lipid peroxidation due to the scavenging abilities of their hydroxyl group (Raj et al., 2011).

In the present study, the phenolic content of aqueous extracts was correlated significantly with the phenolic content of alcoholic extract $(\mathrm{r}=$ 0.448).

\subsection{The flavones content}

Quantities of flavones, calculated using the equation $y=37.125 \mathrm{x}-0.0328\left(\mathrm{R}^{2}=0.994\right)$, are presented in Figure 2.

Flavonoid content ranged from 5.00 \pm 0.004 $\mathrm{mg}$ QE/g for Arctium lappa to $150.60 \pm 0.016$ $\mathrm{mgQE} / \mathrm{g}$ for Populus nigra in ethanol extracts, and from $5.54 \pm 0.002 \mathrm{mgQE} / \mathrm{g}$ Populus nigra to $39.714 \pm 0.019 \mathrm{mg}$ QE/g Thymus vulgaris in the aqueous extracts of the ten plant extracts.

3.3. 2,2-Diphenyl-1-picrylhydrazyl (DPPH) radical-scavenging assay

Table 1. shows the antioxidant activity in terms of free radical scavenging activity of aqueous extract and 98\% EtOH extracts, evaluated using Trolox standard and the regression equation $\mathrm{y}=691.53 \mathrm{x}+4.8201 \quad\left(\mathrm{R}^{2}=0.998\right)$, expressed as Trolox mmols/g of extract.

DPPH is a free radical that accepts an electron or hydrogen radical to become a stable diamagnetic molecule. The reduction capability of DPPH radical was determinated by the decrease in absorbance induced by plant antioxidant (Ksouri et al., 2009). The scavenging effect of ethanol and aqueous extracts expressed as concentration providing $50 \%$ inhibition $\mathrm{IC}_{50}$ was in the following order: Plantago lanceolata $\mathrm{IC}_{50}=$ $31.346 \mathrm{mg} / \mathrm{mL}$ to Serratula tinctoria, Echinaceea angustifolia IC $=3.129 \mathrm{mg} / \mathrm{mL}$ (aqueous extracts) and Symphytum officinale IC ${ }_{50}=30.773 \mathrm{mg} / \mathrm{mL}$ to Althaea officinalis IC $=3.57 \mathrm{mg} / \mathrm{mL}$ (alcoholic extracts).

Among the studied plants, Arctium lappa registered an antioxidant activity record $(0.129 \pm 0.002 \mathrm{mmols}$ Trolox $/ \mathrm{mL})$ in the form of alcoholic extract and Echinaceea angustifolia with a value of $0.122 \pm 0.001 \mathrm{mmol}$ Trolox/mL aqueous extract. The lowest values were recorded for the antioxidant activity of Althaea officinalis (alcoholic extract) and Arctium lappa (aqueous extract).

All of the tested extracts possessed high radical scavenging activity. Significant differences $(\mathrm{P}<0.05)$ were observed among all the extracts $(\mathrm{r}$ $=0.278$ ).

In the analyzed samples of melliferous plant extracts, the $\mathrm{IC}_{50}$ values were correlated with the

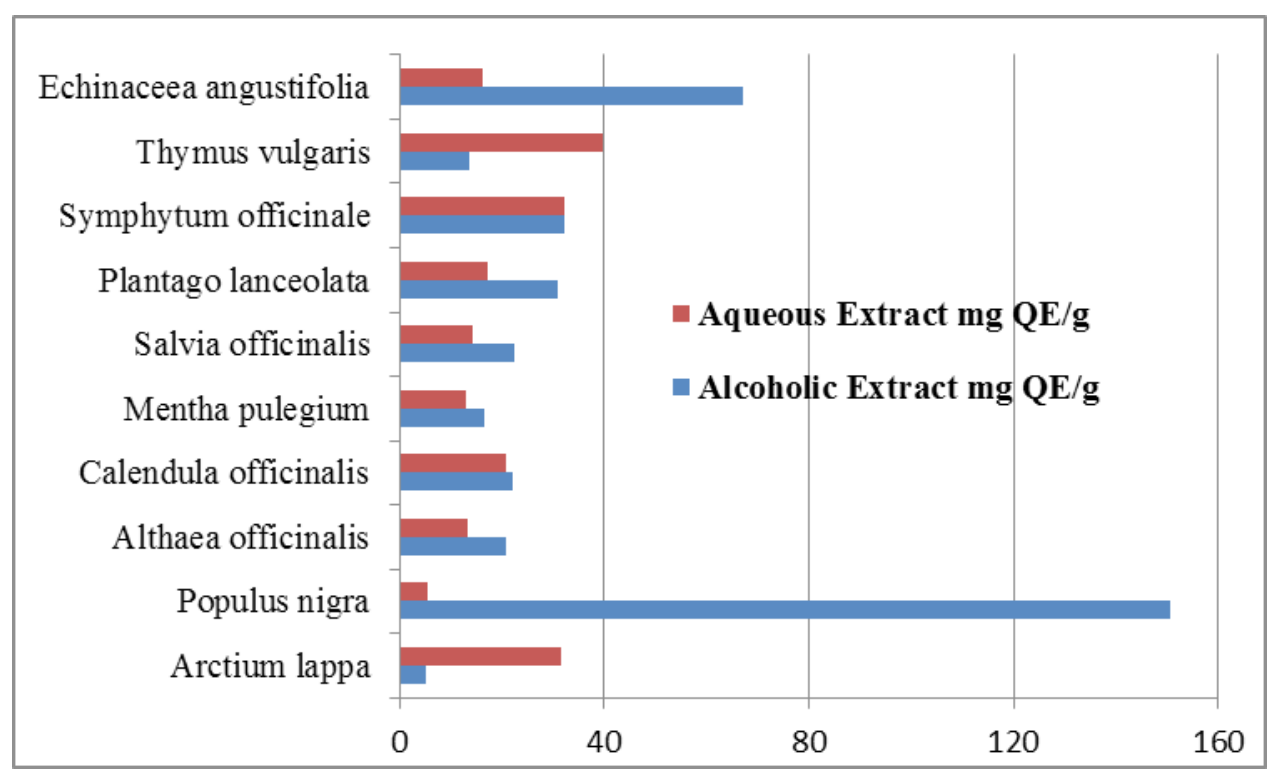

Note: $\mathrm{QE}=$ Quercetin equivalents;

Fig.2. Total flavones content (mg QE/g) 
Tab. 1. Antioxidant activity (mmol Trolox $/ \mathrm{mL}$ )

\begin{tabular}{|c|c|c|c|c|}
\hline \multirow[b]{2}{*}{ Melliferous plants } & Aqueous extracts & Alcoholic extract & \multirow{2}{*}{$\begin{array}{c}\text { Aqueous } \\
\text { extracts }\end{array}$} & \multirow{2}{*}{$\begin{array}{c}\begin{array}{c}\text { Alcoholic } \\
\text { extract }\end{array} \\
(5 \mathrm{mg} / \mathrm{mL})\end{array}$} \\
\hline & \multicolumn{2}{|c|}{ Mean \pm standard deviation } & & \\
\hline Arctium lappa & $0.061 \pm 0.012$ & $0.129 \pm 0.002$ & 9.648 & 28.097 \\
\hline Symphytum officinale & $0.063 \pm 0.013$ & $0.125 \pm 0.001$ & 6.480 & 30.773 \\
\hline Plantago lanceolata & $0.119 \pm 0.003$ & $0.126 \pm 0.0005$ & 31.346 & 8.311 \\
\hline Thymus vulgaris & $0.121 \pm 0.002$ & $0.126 \pm 0.002$ & 17.093 & 3.374 \\
\hline Salvia officinalis & $0.107 \pm 0.083$ & $0.123 \pm 0.001$ & 4.266 & 2.981 \\
\hline Calendula officinalis & $0.120 \pm 0.003$ & $0.065 \pm 0.001$ & 3.129 & 3.019 \\
\hline Althaea officinalis & $0.108 \pm 0.005$ & $0.019 \pm 0.015$ & 3.397 & 2.961 \\
\hline Echinaceea angustifolia & $0.122 \pm 0.001$ & $0.086 \pm 0.003$ & 3.129 & 3.026 \\
\hline Populus nigra & $0.092 \pm 0.008$ & $0.128 \pm 0.001$ & 3.570 & 4.527 \\
\hline Mentha pulegium & $0.101 \pm 0.005$ & $0.125 \pm 0.003$ & 3.615 & 3.110 \\
\hline
\end{tabular}

antioxidant capacity. As the inhibition percent of $5 \%$ plant extract concentration, which inhibits the $0.02 \mathrm{mg} / \mathrm{mL}$ DPPH solution is higher, the plant extracts will be richer in antioxidant compounds.

This findings indicate that the aqueous and ethanolic extracts of Populus nigra, Echinaceea angustifolia and Thymus vulgaris are a good potential source of natural antioxidants, polyphenols and flavones, for preventing radicalmediated oxidative damage (Table 2).

A positive correlation $(r=0.278)$ was found, suggesting that the antioxidant activity of the melliferous plants is due to a great extent to polyphenol and flavones contents (Kiselova et al., 2006).

The results of the investigation of the content and activity of phenolic antioxidants in medicinal plants have been published in many studies using different extraction methods (Maslennikov et al., 2014). In the studied literature, the total phenolic contents for the same type of melliferous plant samples are the following - ethanolic extract of Mentha pulegium: $13.4 \pm 0.2 \mathrm{mg} \mathrm{GAE} / \mathrm{g}, 0.8 \pm 0.1 \mathrm{mg}$ GAE/g for Thymus vulgaris, $15.6 \pm 0.1 \mathrm{mg} \mathrm{GAE} / \mathrm{g}$ for Salvia officinalis (Proestos et al., 2013), 11.7 \pm 1.1 $\mathrm{mg} / \mathrm{g}$ in Echinacea purpurea (L.), $2.7 \pm 0.2 \mathrm{mg} / \mathrm{g}$ in Althaea officinalis L.(Maslennikov et al., 2014), $16.94 \pm 1.7 \mathrm{mg} \mathrm{GAE} / \mathrm{g}$ in Arctium lappa (Song et al., 2010), 106.57 $\pm 0.47 \mathrm{mg} \mathrm{GAE} / \mathrm{g}$ in Populus nigra (Benedec et al., 2014).
The antioxidant activity of the alcoholic extract found in the literature studies was: $14.79 \pm 1.21$ $\mathrm{mg} / \mathrm{g}$ Mentha piperita L., $1.65 \pm 0.12 \mathrm{mg} / \mathrm{g}$ Althaea officinalis $L ., 1.33 \pm 0.11 \mathrm{mg} / \mathrm{g}$ Salvia officinalis L., $0.79 \pm 0.06 \mathrm{mg} / \mathrm{g}$ Thymus vulgaris, $0.19 \pm 0.01$ $\mathrm{mg} / \mathrm{g}$ Echinaceea purpurea (L.) (Maslennikov et al., 2014), 76.66 $\pm 0.53 \mu \mathrm{mol}$ Trolox/g, Arctium lappa (Song et al., 2010), 205.9 \pm 6.9 Trolox/mg plant Populus nigra (Benedec et al., 2014).

These results were similar to those of Kiselova et al. (2006), who studied the correlation between antioxidant activity and polyphenol content of aqueous extracts from Bulgarian herbs and they mentioned that those medicinal plants are an excellent source of antioxidants.

In this study, the plant extracts exhibited antioxidant activity higher or comparable to the reference foreign plants (Maslennikov et al., 2014; Song et al., 2010; Benedec et al., 2014).

\section{CONCLUSION}

In conclusion, we might say that our results further support the view that medicinal plants are promising sources of natural antioxidants. Total phenol content and total antioxidant capacity differ significantly among the 10 selected melliferous plant extracts. There was significant linear correlation between phenolics concentration and DPPH. 
The best results were obtained for Populus nigra (alcoholic extract), Thymus vulgaris (aqueous extract): high phenolic concentration; very high flavones content for: Thymus vulgaris (aqueous extract) and Populus nigra (alcoholic extract) and high antioxidant activity expressed as $\mathrm{IC}_{50}$ value: Calendula officinalis and Echinacea angustifolia aqueous extracts and Salvia officinalis and Althaea officinalis in alcoholic extract. The in vitro antioxidative properties of all our extracts show that they are valuable melliferous plants for their high potential of biologically active compounds and on account of being a good source for bee products.

Aknowledgements: Financial support was granted by the project Partnerships in Priority Areas Programme - PN II, developed with the support of MEN - UEFISCDI, project no. 148/2014 and POS CCE project RoBeeTech, no. 206/2010.

\section{REFERENCES}

1. Pryor WA, (1991). The antioxidant nutrients and disease preventions. What do we know and what do we need to find out. Am. J. Clin. Nutr. 53:S391-S393.

2. Brand-Williams W, Cuvelier ME, Berset C, (1995). Use of a free radical method to evaluate antioxidant activity. LWT Food Sci.Technol. 28:25-30.

3. Chun Hu, Kitts DD. (2000). Studies on the Antioxidant Activity of Echinacea Root Extract.J. Agric. Food Chem. 48:1466-1472.

4. Macukanovic-Jocic M, Duletic-Laucevic S, JOCIC G, (2004). Nectar production in three melliferous species of lamiaceae in natural and experimental conditions. Acta Veterinaria (Beograd), 54(5-6):475-487.

5. Pârvu C. (2005). Enciclopedia plantelor. Plante din flora României. Ed. Tehnică. București. Vol.4.

6. Kiselova Y, Ivanova D, Chervenkov T, Gerova D, Galunska B, Yankova T, (2006). Correlation between the In Vitro Antioxidant Activity and Polyphenol Content of Aqueous Extracts from Bulgarian Herbs. John Wiley \& Sons, Ltd. 20:961-965

7. Chang HC, Huang GJ, Agrawal DC, Kuo CL, Wu CR, Tsay HS, (2007). Antioxidant activities and polyphenol contents of six folk medicinal ferns used as "Gusuibu".Botanical Studies.48: 397-406.

8. Wojdylo A, Oszmianski J, Czemerys R, (2007). Antioxidant Activity and phenolic compounds in 32 selected herbs. Food Chemistry 105:940-949.

9. Al-Mustafa AH. Thunibat OYA, (2008). Antioxidant Activity of some Yordanian Medicinal Plants Used. Traditionally for Treatment of Diabetes, Pakistan Journal of Biological Sciences 11(3):351-358.

10. Kohri S, Fujii H, Oowada S, Endoh N, Sueishi Y, Kusakabe M, Shimmei M, Kotake Y. (2009). An oxygen radical absorbance capacity-like assay that directly quantifies the antioxidant's scavenging capacity against AAPH-derived free radicals. Anal. Biochem., 386: 167-171.

11. Song FL, Gan RY, Zhang Y, Xiao Q, Kuang L, Li HB, (2010). Total Phenolic Contents and Antioxidant Capacities of Selected Chinese Medicinal Plants. Int. J. Mol. Sci., 11:23622372.

12. Dudonné S, Poupard P, Coutière $P$, Woillez M, Richard T, Mérillon JM, Vitrac X, (2011).

13. Phenolic Composition and Antioxidant Properties of Poplar Bud (Populus nigra) Extract: Individual Antioxidant Contribution of Phenolics and Transcriptional Effect on Skin Aging. J. Agric. Food Chem. 59 (9):4527-4536.

14. Neag E, Păun G, Radu LG, (2011). Phytochemical study of some symphytum officinalis extracts concentrated by membranous procedures, U.P.B. Sci. Bull., Series B, Vol. 73:3.

15. Raj PK, Irudayaraj V, Johnson M, Patric Raja D. (2011). Phytochemical and antibacterial activity of epidermal glands extract of Christella parasitica (L.) H.Lev. Asian Pac. J. Trop. Biomed. 1:8-11.

16. Azizov UM,. Khadzhieva UA, Rakhimov DA, Mezhlumyan G, Salikhov SA. (2012). Chemical composition of dry extract of Arctium lappa roots. Chemistry of Natural Compounds, 47:6.

17. Alzahrani HA, Alsabehi R, Boukra L, Abdellah F, Bellik Y, Bakhotmah BA (2012). Antibacterial and antioxidant potency of floral honeys from different botanical and geographical origins. Molecules, 17: 10540-10549.

18. Beara IN, Lesjak MM, Orčić DZ, Simin NĐ, Četojević-Simin DD, Božin BN, Mimica-Dukić NM, (2012). Comparative analysisofphenolicprofile, antioxidant, anti-inflammatory and cytotoxic activity of two closely-related Plantain species: Plantago altissima L. and Plantago lanceolata L. LWT - Food Science and Technology. 47(1):64-70.

19. Khalid KA, Teixeira de Silva JA, Biology of Calendula officinalis Linn: Focus on Pharmacology, Biological Activities and Agronomic Practices, (2012). Medicinal and Aromatic Plant Science and Biotechnology. 6(1):12-27.

20. Naz R, Anis M, (2012). Acceleration of Adventitious Shoots by Interaction Between Exogenous Hormone and Adenine Sulphate in Althaea Officinalis L. Springer Science Business Media.168:1239-1255.

21. Pérez-Pérez E, Vit P, Huq F, (2013). Flavonoids and polyphenols in studies of honey antioxidant activity. International Journal of Medicinal Plant and Alternative Medicine. 1(4): 063-072.

22. Proestos C, Lytoudi K, Mavromelanidou OK, Zoumpoulakis P, Sinanoglou VJ, (2013). Antioxidant Capacity of Selected Plant Extracts and Their Essential Oils, Antioxidants, 2:11-22.

23. Skotti MN, Mat I, Lim V, Ahmad Ruzita (2013). Antioxidant Activity and Phenolic Content of Streblus asper Leaves from Various Drying Methods. Antioxidants 2:156166. Pérez-Pérez E, Vit P, Huq F, (2013). Flavonoids and polyphenols in studies of honey antioxidant activity. International Journal of Medicinal Plant and Alternative Medicine, 1(4):063-072. 
24. Antonie I, (2014). The Biodiversity of the melliferous plants management, economic engineering in agriculture and rural development. In the surroundings of the town Sebes (Alba county) and their economical importance. Scientific Papers Series. 14(4):1.

25. Benedec D, Oniga I, Mureșan B, Mot AC, Damian G, Nistor A, Dumitrescu RS, Hangan D, Duma M, Vlase L, (2014). Contrast between water and ethanol based antioxidant assays: Aspen (Populus tremula) and black popular (Populus nigra) extracts as a case study. Journal of Food Quality ISSN 1745-4557.

26. Maslennikov PV, Chupakhina GN, Skrypnik LN, (2014). The Content of Phenolic Compounds in Medicinal Plants of a Botanical Garden (Kaliningrad Oblast). Biology Bulletin, 41(2):133-138.

27. Shahmohamadi R, Sariri R, Rasa M, Aghamali M, (2014). Antioxidant activity oF Gilan Mentha pulegium During
Growth. Pakistan Journal of Biological Sciences 17(3):380387.

28. Herman A., (2014). Comparison of Antimicrobial Activity of Essential Oils, Plant Extracts and Methylparaben in Cosmetic Emulsions: 2 Months Study. Indian J Microbiol.54(3):361-364.

29. Ghavi PP, (2015). The extraction process optimization of antioxidant polysaccharides from Marshmallow (Althaea officinalis L.) roots. International Journal of Biological Macromolecules. 75: 51-57.

30. Pașca C, Mărghitaș LA, Dezmirean D, Bobiș O, Bonta V, Mărgăoan R, Chirilă F, Fit N, (2015). The assessment of the antibacterial activity of some plant extracts on normal and pathogenic microflora from milk. Scientific Papers: Animal Science and Biotechnologies, 48 (1). 
